\title{
Effect of Weaning Age on Growth and Slaughter Characteristics of Grasscutters (Thryonomis swinderianus) Raised under Intensive Management in the Humid Tropics
}

\author{
A. J. Henry ${ }^{1}$, S. N. Ibe $^{2} \&$ B. O. Asuquo ${ }^{1}$ \\ ${ }^{1}$ Department of Animal Science, University of Calabar, Calabar, Nigeria \\ ${ }^{2}$ Department of Non-Ruminant Animal Production, Michael Okpara University of Agriculture, Umudike, Abia \\ State, Nigeria \\ Correspondence: A. J. Henry, Department of Animal Science, University of Calabar, Calabar, Nigeria. Tel: \\ 234-803-723-9456. E-mail: affys.henry@yahoo.com
}

\author{
Received: April 24, 2012 Accepted: May 20, 2012 Online Published: November 15, 2012 \\ doi:10.5539/jas.v4n12p232 URL: http://dx.doi.org/10.5539/jas.v4n12p232
}

\begin{abstract}
An experiment was conducted to assess the effect of age at weaning on growth and slaughter characteristics of grasscutters (Thryonomis swinderianus). This study was carried out using thirty (30) mixed sex six weeks old juvenile grasscutters, collected ten each from grasscutter populations weaned at different ages of 2, 4 and 6 weeks. The completely randomized design was adopted for the study, with each treatment group (weaning age) being comprised of five replicates of two animals each. Results at the end of the experimental period of fourteen weeks showed that average weekly and daily feed intake were significantly $(p>0.01)$ influenced by weaning age of the animals. More so, among the carcass traits under evaluation only the tail and neck weights differed $(p>0.05)$ between the treatment groups. In addition, the small intestine and caecum weights were significantly $(p>0.05)$ affected by age at weaning of grasscutters.
\end{abstract}

Keywords: grasscutter, weaning age, growth characteristics, slaughter traits, intensive management

\section{Introduction}

The importance of animal products as a source of protein for human development cannot be overemphasized. Madubuike (2004) reported that protein do not only possess better amino acid assortments, but are more readily assimilated and are devoid of enzyme inhibitors and other anti-nutritional factors common in plant proteins. However, the trend in livestock production in Nigeria has been largely dependent on domestic livestock (Lameed \& Ogundijo, 2006), which cannot supply the projected animal protein requirement for a population of over 140 million in the country (Wogar et al., 2007). Furthermore, Lameed and Ogundijo (2006) observed that animal protein production in Nigeria from domestic livestock has been falling steadily by about $1.4 \%$ annually, while human population has been increasing at an annual rate of $3.3 \%$. Therefore, there is need to bridge the huge animal protein gap before Nigerians could attain the Food and Agriculture Organization's recommended daily animal protein intake (Idufeko, 1984; Igben, 2000). Various authors had suggested that the shortage of animal protein in the third world countries can be ameliorated by improving the existing conservation programme of wildlife particularly the domestication of rodents that are tractable, prolific and widely accepted to the public for consumption (Ajayi, 1971; Mbah, 1989). The grasscutter was reported by Clottey (1981) as the most preferred among wild rodents wider domestication as well as an alternative with a promising future. More so, raising grasscutter in captivity still remains a relatively new initiative which requires further investigations on its successive and successful rearing. As such, there is need to provide more information on the performance of grasscutter weaned at different ages. According to Chineke et al. (2002), variations exist in the growth performance of different breeds of animals. Studies have identified weaning age among other factors as influencing post-weaning growth performance of rabbits (Afifi \& Emara, 1988; McNitt \& Luke Fahr, 1996). The economics of livestock production depends on post-weaning growth performance of young animals as this influences the rate of attainment of market weight. Xiccato et al. (2000) in a study on rabbits observed that early weaning of young rabbits could permit increased reproduction rate without negative effects on litters and does performance. Research has also shown that early weaning can reduce pathogen transmission between litters and 
doe (Scholant, 1988). More importantly, the precocious nature of the grasscutter could be an added advantage for its survival at early age without a doe. This research was conducted to assess the effect of weaning age on growth and slaughter characteristics of grasscutters.

\section{Materials and Methods}

\subsection{Experimental Site}

The research was conducted at a grasscutter research unit under the supervision of the Department of Animal Science, University of Calabar, Calabar, Cross River State, Nigeria.

\subsection{Experimental Animals and Management Procedure}

Thirty (30) mixed sex six weeks old juvenile grasscutters randomly selected ten each from three populations of pups weaned at different ages of 2, 4 and 6 weeks (treatment groups - designated as $\mathrm{WA}_{2}, \mathrm{WA}_{4}$ and $\mathrm{WA}_{6}$, respectively) were used for the study. Each treatment comprised of five replicate of two animals each.

\subsection{Housing}

Guidelines for the construction of animal research unit were obtained from Animal Care Information Service (2004) for this animal type. The animals were housed in cells measuring 51 x 50 x $44 \mathrm{~cm}$ within a concrete housing. The entrance of each cell was constructed using wooden frames, wire mesh and one-quarter inch rods. This was to allow for adequate ventilation. Furthermore, each cell's entrance was screened with zinc to prevent excessive in-flow of air into the cells because of the nature of the fur (non-interlocking) of the grasscutter to prevent pneumonia.

\subsection{Feeding}

Grasscutters were maintained under a mixed feeding regime with concentrate formulated to contain $24 \%$ crude protein and $2340 \mathrm{kcal} / \mathrm{kg}$ energy (Table1). Elephant grass (Pennisetum purpureum) was served as supplement and provided ad libitum as water. Routine sanitation was carried out throughout the experimental period of fourteen weeks.

Table 1. Gross composition of growers' experimental diet (g)

\begin{tabular}{ll}
\hline Ingredients & Diet $(\mathrm{g} / 100 \mathrm{~g})$ \\
\hline Maize & 36.50 \\
Soya bean meal & 34.00 \\
Palm kernel cake & 10.00 \\
Wheat offal & 15.00 \\
Salt & 0.50 \\
*Vitamin premix & 0.50 \\
Bone meal & 3.00 \\
Lysine & 0.30 \\
Methionine & 0.20 \\
Total & 100.00 \\
Calculated nutrient composition (\%) & \\
Crude protein & 24.00 \\
Crude fibre & 8.14 \\
ME(Kcal/kg) & 2340.00 \\
\hline
\end{tabular}

*vitamin premix supplied the following additional micronutrients: vitamins A: 10,000 u; vit. $\mathrm{D}_{3} 20,000$ iu; Vit.E 25 g; Vit. 2.5 g; Vit. $B_{1} 3$ g; Vit.B 6 g; Niacin, 55 g; Calciumpenthothenate, 11.5 g; Vit.B 6 ; Vit. $B_{12}, 0.75$ g; Cholinechloride, $250 \mathrm{~g}$; folicacid, $1 \mathrm{~g}$; Biotin, $0.05 \mathrm{~g}$; Mn., $46 \mathrm{~g}$; Fe, $32 \mathrm{~g}$; Zn, $40 \mathrm{~g}$; Cu, 8 g; Iodine, 0.8 g; Co., 0.4 g; Se., 0.6 g; Riboflavin 5 g; DL-methionine 50 g; L-lysine, 120 g; Sipramycin, 5 g; antioxidant (HTH) 120 g.

\subsection{Data Collection}

Data collected for growth parameters were: weekly body weight, weekly feed intake, weight gain and feed conversion ratio (FCR). For slaughter traits, using a 10kg mechanical dial platform scale the following weights were obtained: fasted weight, bled carcass and dressed carcass weights. The primal cuts and internal organ weights were obtained using the A and A digital electronic scale.

Relative internal organ weights were determined using the formula: 


\subsection{Experimental Design and Statistical Analysis}

The completely randomized design (CRD) was adopted for research. The model for analysis of variance was:

$Y_{i j}=\mu+R_{i}+e_{i j}$

$\mathrm{Y}_{\mathrm{ij}}=$ Individual observation on the jthgrasscutter of the ith treatment

$\mu=$ Overall mean of all observations

$\mathrm{R}_{\mathrm{i}}=$ Fixed effect of weaning age ( $\left.\mathrm{I}=1-3\right)$

$\mathrm{e}_{\mathrm{ij}}=$ random error, identically and independently normally distributed with zero mean and constant variance.

Significant means were separated using Duncan's Multiple Range Test (Duncan, 1955).

\section{Results}

Growth performance of juvenile grasscutters weaned at different ages is as presented in Table 2. Results of statistical analysis reveal that body weight and weight gains of grasscutters were not significantly $(\mathrm{P}>0.05)$ different across the treatment groups. The performance trend for total weight gain, weekly and daily weight gains were four weeks $>$ two week $>$ six weeks. Average daily and weekly feed intake values of grasscutters post weaning revealed a reverse in trend as significant $(\mathrm{p}<0.05)$ weaning age effects were observed for both parameters. Feed conversion ratio (FCR) ranged from 8.56 to 24.69 across the treatment groups. Grasscutters weaned at four weeks of age recorded a better $(\mathrm{p}>0.05)$ value followed by those weaned at six weeks while grasscutters weaned at two weeks recorded the lowest value of 24.69. Percentage mortality was $8.69,16.66$ and 6.25 for $\mathrm{WA}_{2}, \mathrm{WA}_{4}$ and $\mathrm{WA}_{6}$, respectively.

Post weaning growth trend is as presented in Figure 1. It was observed from graphical presentation, that growth pattern of these animals followed the sigmoid curve of the general growth pattern.

Carcass characteristics and most of the primal cuts considered did not differ $(\mathrm{p}>0.05)$ significantly across the treatment groups (Table 3). Live weight values were 1546.81, 1636.79 and $1419.32 \mathrm{~g}$ for grasscutters weaned at two, four and six weeks of age, respectively.

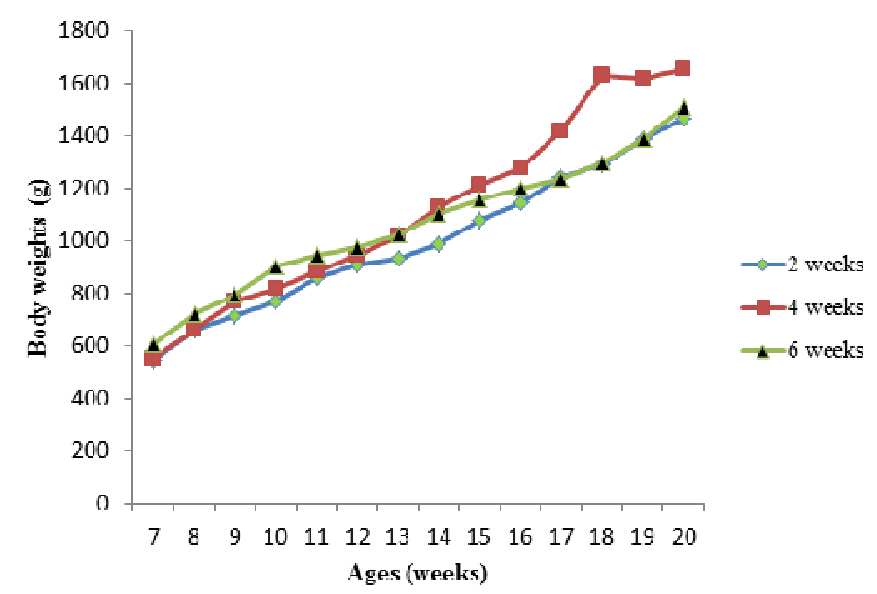

Figure 1. Mean weekly body weights (g) of juvenile grasscutters from weeks 7 to 20

Dressed carcass and carcass weights followed similar pattern as live weight $\left(\mathrm{WA}_{4}>\mathrm{WA}_{2}>\mathrm{WA}_{6}\right)$ with animals weaned at four weeks recording higher $(\mathrm{p}>0.05)$ values. Dressing percentages obtained in this study ranged from 88.83 to $89.07 \%$ across the treatment groups. Results of this study revealed that among the primal cuts evaluated, only the neck and tail were significantly $(\mathrm{P}<0.05)$ affected by age at weaning for grasscutters. For other cuts such as the head, fore limbs and hind limbs, animals weaned at four weeks recorded heavier weights $(p>0.05)$ than the other two groups. But for the back and loin cuts, animals weaned at six weeks recorded heavier cuts $(p>0.05)$. The weights of the lung, liver, large intestine, caecum and kidney were not influenced by weaning age of the grasscutters (Table 4). The findings of this research showed that the weights of the heart and lungs decreased as 
weaning age increased. The small intestine was the only organ significantly $(\mathrm{P}<0.05,0.01)$ affected by weaning age of the grasscutters.

Relative organ weights of grasscutters weaned at different ages are as presented in Table 5. Statistical analysis showed that weaning age did not significantly $(\mathrm{P}>0.05)$ affect the parameters measured except for the small intestine and caecum. Observations from the study showed that caecum weight was highest $(\mathrm{p}>0.05)$ for grasscutters weaned at two weeks (52\%) while those weaned at four weeks recorded the least value of $3.55 \%$.

Table 2. Effect of weaning age on post- weaning growth performance of juvenilegrasscutters $(n=30)$

\begin{tabular}{llllll}
\hline Weaning Ages & & & & & \\
\hline Parameters & 2 weeks & 4 weeks & 6 weeks & \pm SEM & Significance \\
\hline Av. Initial body weight (g) & 471.53 & 471.16 & 522.48 & 2.84 & NS \\
Av. Final body weight (g) & 1464.67 & 1653.88 & 1505.01 & 5.21 & NS \\
Av. Daily weight gain (g) & 10.13 & 12.07 & 10.03 & 0.56 & NS \\
Av. Weekly weight gain (g) & 70.94 & 84.48 & 70.18 & 1.48 & NS \\
Total weight gain (g) & 993.14 & 1182.72 & 982.53 & 5.54 & NS \\
Av. Weekly feed intake (g) & $1497.12^{\mathrm{a}}$ & $1455.55^{\mathrm{ab}}$ & $1133.79^{\mathrm{c}}$ & 7.36 & $* *$ \\
Av. Daily feed intake(g) & $213.88^{\mathrm{a}}$ & $207.94^{\mathrm{ab}}$ & $161.97^{\mathrm{c}}$ & 1.27 & $* *$ \\
FCR & 24.69 & 8.56 & 19.50 & 1.49 & NS \\
Mortality (\%) & 0.00 & 0.00 & 0.00 & - & - \\
\hline
\end{tabular}

a,b,c: Means within rows with different superscripts are significantly $(\mathrm{P}<0.05)$ different;

\pm SEM: standard error of means; NS: Not significant; $n=$ number of progeny; FCR: feed conversion ratio; Av.:average

Table 3. Effect of weaning age on carcass characteristics of juvenile grasscutters

\begin{tabular}{|c|c|c|c|c|c|}
\hline \multicolumn{6}{|c|}{ WEANING AGES } \\
\hline $\begin{array}{c}\text { Carcass } \\
\text { Characteristics }\end{array}$ & 2 WEEKS & 4 WEEKS & 6 WEEKS & $\pm \mathrm{SEM}$ & Significance \\
\hline Live weight (g) & 1546.81 & 1636.79 & 1419.32 & 5.45 & NS \\
\hline Carcass weight (g) & 1370.03 & 1456.23 & 1264.02 & 5.12 & NS \\
\hline $\begin{array}{c}\text { Dressing }(\%) \\
\text { Primal Cuts (g) }\end{array}$ & 89.07 & 89.04 & 88.83 & 0.19 & NS \\
\hline Head & 119.71 & 123.32 & 118.35 & 0.84 & NS \\
\hline Tail & $33.69^{\mathrm{a}}$ & $19.06^{\mathrm{bc}}$ & $19.99^{c}$ & 1.49 & $*$ \\
\hline Fore limbs & 146.34 & 159.84 & 129.39 & 2.04 & NS \\
\hline Hind limbs & 276.64 & 286.57 & 271.24 & 1.45 & NS \\
\hline Neck & $65.15^{\mathrm{ab}}$ & $66.46^{\mathrm{a}}$ & $44.53^{\mathrm{c}}$ & 1.83 & $*$ \\
\hline Loin & 76.32 & 72.89 & 85.09 & 1.31 & NS \\
\hline Back & 371.68 & 420.81 & 391.93 & 2.59 & NS \\
\hline
\end{tabular}

Note: ${ }^{a, b, c}$ : Means within the same row with different superscript differ significantly $(\mathrm{p}<0.05)$. 
Table 4. Effect of weaning age on internal organ weights of grasscutters $(\mathrm{g})$

\begin{tabular}{cccccc}
\hline \multirow{2}{*}{ Parameters } & \multicolumn{5}{c}{ Weaning Ages } \\
\cline { 2 - 6 } & 2 WEEKS & 4 WEEKS & 6 WEEKS & \pm SEM & Significance \\
\hline Heart & 10.45 & 9.18 & 8.14 & 0.56 & NS \\
Lung & 10.47 & 9.20 & 8.61 & 0.51 & NS \\
Liver & 21.95 & 23.98 & 20.07 & 0.73 & NS \\
Small intestine & $30.06^{\mathrm{c}}$ & $45.16^{\mathrm{a}}$ & $41.49^{\mathrm{ab}}$ & 3.72 & $* *$ \\
Large intestine & 54.11 & 58.08 & 51.49 & 0.95 & NS \\
Caecum & 80.56 & 66.33 & 59.88 & 1.67 & NS \\
Kidney & 6.58 & 6.28 & 7.02 & 0.32 & NS \\
\hline
\end{tabular}

Values are means of five grasscutters;

a,b,c: means within the same row with different superscript differ $(p<0.01)$ significantly.

$*(p<0.01) ; \pm$ SEM: standard error of means; NS: Not significant.

Table 5. Effect of weaning age on relative organ weights of grasscutters (\%)

\begin{tabular}{cccccc}
\hline \multirow{2}{*}{ Parameters } & \multicolumn{5}{c}{ Weaning Ages } \\
\cline { 2 - 6 } & 2 WEEKS & 4 WEEKS & 6 WEEKS & \pm SEM & Significance \\
\hline HEART & 0.67 & 0.56 & 0.58 & 0.13 & NS \\
LUNG & 0.67 & 0.56 & 0.61 & 0.12 & NS \\
LIVER & 1.42 & 1.47 & 1.42 & 0.08 & NS \\
SMALL INTESTINE & $1.95^{\mathrm{C}}$ & $2.78^{\mathrm{AB}}$ & $2.93^{\mathrm{A}}$ & 0.38 & $* *$ \\
LARGE INTESTINE & 3.48 & 3.57 & 3.63 & 0.14 & $\mathrm{NS}$ \\
CAECUM & $5.2^{\mathrm{A}}$ & $3.55^{\mathrm{BC}}$ & $3.64^{\mathrm{B}}$ & 0.50 & $*$ \\
KIDNEY & 0.42 & 0.38 & 0.49 & 0.13 & $\mathrm{NS}$ \\
\hline
\end{tabular}

Values Are Means Of Five Grasscutters.

${ }^{a, b, c}$ : means within the same row with different superscripts differ $(\mathrm{p}<0.01)$ significantly;

$*(p<0.05), * *(p<0.01) ; \pm$ SEM: standard error of means; NS: Not significant.

\section{Discussion}

\subsection{Body Weights and Weight Gains}

Several authors have reported different values for total weight gain of grasscutters. Annor et al. (2008) reported values of $225 \mathrm{~g}, 275 \mathrm{~g}$ and $625 \mathrm{~g}$ as total weight gain for grasscutters at the end of an experiment that lasted for 24 weeks. In another study by Obi et al. (2008) where performance of grasscutters were assessed when fed four different conventional forage, the total weight gain reported were between $1024 \mathrm{~g}$ and $1121 \mathrm{~g}$. Karikari and Nyameasem (2009) reported values of $650 \mathrm{~g}, 1110 \mathrm{~g}$ and $1190 \mathrm{~g}$ as total weight gain for grasscutters fed concentrate diets containing varying levels of guinea grass. Total weight gain obtained in this study (Table 1) were higher than those reported by Annor et al. (2008) but compared favourably with those of Obi et al. (2008) and Karikari and Nyameasem (2009).

The higher $(\mathrm{P}>0.05)$ final body weight for grasscutters weaned at four weeks (Table 1) of age may be accounted for by the high weekly body weight gain. The lower body weight for pups weaned at two weeks of age could be attributed to stress accompanying early separation of pups from does as well as the level of efficiency of the early weaned grasscutters to digest and utilize the dry matter content of its feeds. As studies have shown that fibre levels in the diet of grasscutters is associated with digestibility of dry matter, protein and fat which could lead to reduction in growth rate (Vanzyl et al., 1999). 
Results of this study are similar to reports of Zita et al. (2007) where they observed no significant $(\mathrm{P}>0.05)$ effect of weaning age and nutrient digestibility on the performance of broiler rabbits. Similarly, Xiccato et al. (2000) did not also observe any significant influence of weaning age on the growth of rabbits, although Fortun-Lamothe et al. (2002) had showed that early weaning provided higher viability and fastest growth in weaned rabbits. On studies involving other animal species, some researchers have shown that weaning age did not significantly influence growth performance of kids. For instance, Ugur et al. (2004) reported non-significant influence of weaning age on weight gains of kids of Turkish Saanen goat. Also in accordance with the results of this study, Caneque (2001) and Selaive-Villarroel et al. (2008) reported no effect $(\mathrm{P}>0.05)$ of weaning age on total lamb weight gain and daily weight gain.

General observation in this study showed that grasscutters weaned at two weeks of age $\left(\mathrm{WA}_{2}\right)$ compared favourably in post-weaning growth performance with those weaned at four $\left(\mathrm{WA}_{4}\right)$ and six $\left(\mathrm{WA}_{6}\right)$ weeks of age without mortality. Similar results were reported when effect of weaning age was assessed on body weight (Chen et al., 1978) and live weight (Tùmova et al., 2006) of rabbits weaned at different ages. The growth pattern of juvenile grasscutters post-weaning followed the sigmoid curve of the general growth pattern (Figure 1). From the graph, grasscutters weaned at four weeks were seen to perform better than grasscutters of the other two treatments from the $14^{\text {th }}$ to $20^{\text {th }}$ week of age. In comparing the effect of weaning age on post-weaning growth rate, it was observed that pups weaned at six weeks $\left(\mathrm{WA}_{6}\right)$, which had a longer suckling period did not show better performance than those weaned earlier. Selaive-Villarroel et al. (2008) observed and reported similar results for lambs of Morada Nova breed weaned at different ages.

\subsection{Feed Intake}

Grasscutters weaned at 2 weeks of age consumed more feed when compared to those weaned at 6 weeks. The results of feed conversion ratio explain the differences in body weights and weight gains resulting from feed intake. Results of this study on feed intake could be attributed to the early development of the digestive tract of grasscutters weaned at 2 weeks as feed consumption has been found to influence the development of the digestive tract, a point made by Zita et al. (2007). Earlier studies have revealed that solid feed consumption led to early development of the digestive tract (Gallois et al., 2003). Xicatto et al. (2000) and Tùmova et al. (2006) opined that digestive tract development does not affect feed consumption of early weaned rabbits. Unlike these researchers, Fonteh et al. (2005) observed that the early-weaned kits overcame weaning stress and also developed the capacity to handle efficiently solid and fibrous feed than the late-weaned kits. This point was expressed in this study judging from the significant value recorded for feed intake of pups weaned after 2 weeks. Results of this study agree with reports of Gallois et al. $(2003,2004)$ who demonstrated that feed consumption was higher for early-weaned rabbits in comparison to those weaned at 35 days of age, although weaning age differed between both studies.

\subsection{Feed Conversion Ratio (FCR)}

The FCR values obtained in this research are better than the values of 543.24, 82.30 and 119.38 reported for grasscutters at the end of a 24 weeks feeding trial (Annor et al., 2008). These values are however higher than the value ranges of 1.66 to 3.52 (Wogar et al., 2007), 1.81 and 6.95 (Henry \& Njume, 2008). 4.86 to 5.04 (Obi et al., 2008 ) and 4.8 to 7.5 (Karikari \& Nyameasem, 2009) reported for grasscutters by various researchers. The variation in FCR values may be as a result of the differences in experimental diets used by different authors and feeding regimes in practice while carrying out the various experiments. However, in a study using Fulani calves weaned at different ages, Ogundola (1981) reported no significant effect of weaning age on FCR values for the different groups of calves.

\subsection{Mortality}

Mortality has been reported to be affected by age at weaning (Zita et al., 2007). In this study, no mortality was recorded throughout the experimental period of fourteen weeks. In an earlier study by Schrage and Yewadan (1999), a weaning age of 6 weeks was suggested based on the high post-weaning mortality when animals were weaned at 4 weeks. Furthermore, the authors recorded an $11 \%$ post-weaning mortality for grasscutters weaned at 6 weeks of age. Adu (2003) in his report on post-weaning mortality quoted a percentage of 1.4 for grasscutters weaned at 4 weeks. The zero mortality observed in this study showed that age at weaning did not affect mortality of grasscutters post-weaning, indicating that diverse factors may have to the mortality recorded by other researchers. Various factors have been identified to cause post-weaning mortality such as housing [unit space per grasscutter post-weaning (Adu, 2002); materials used for constructing grasscutter housing (Ogunjobi, 2008); 
nutrition, inadequate and unbalanced feeding (Majiyagbe \& Lamorde, 1997)] and surface area of feed available to the animal. Results of this research show that early weaning ( 2 weeks of age) would return does for mating earlier and therefore accelerate breeding rate.

\subsection{Slaughter Characteristics of Grasscutters}

The non-significant influence of weaning age on live weight of grasscutters suggests that the growth rate of this animal is independent of weaning age. These results agree with the findings of Attah et al. (2006) who reported that carcass weight increased as live weight increased. However, different researchers have reported different experimental effect on carcass characteristics of grasscutters. For instance, in a feeding trial by Karikari and Nyameasem (2009) to assess the effect of feeding grasscutters concentrate diet containing varying levels of guinea grass, these authors reported significant differences in carcass characteristics of grasscutters. The dressing percentages obtained in this study were higher than reported values of $54 \%$ (Jori et al., 1995), 50.41 to $55.26 \%$ (Annor et al., 2008) and 55.00 to $60.30 \%$ (Karikari \& Nyameasem, 2009) but are comparable to the range of 65 to $80 \%$ (Fayenuwo et al., 2003) and 71.80 to $82.30 \%$ (Henry \& Njume, 2008) reported for grasscutters. These percentages for grasscutters compared competitively with those of rabbits, cockerel and broiler with dressing percentages ranging between 73 and 77\% (Ajayi \& Tewe, 1983; Martin, 1983; Olomu et al., 2003). Gillespie (1998) and Kebede et al. (2008) reported that dressing percentage is influenced by several factors some of which included amount of gut fill, slaughter weight, degree of muscling, slaughter age, degree of fatness and nutrition of the animal. Osei and Twumasi (1989) reported that poor tissue deposition resulted from poorly-digested feed which could affect carcass characteristics of an animal.

\subsection{Primal Cuts}

Results of this study revealed that among the primal cuts taken only the tail and neck were significantly $(\mathrm{P}<0.05)$ affected by weaning age of grasscutters. Grasscutters weaned at 2 weeks recorded the highest tail weights $(33.69 \mathrm{~g})$ while the highest neck weight of $66.46 \mathrm{~g}$ was recorded for those weaned at four weeks of age. It was also observed that neck weights did not differ significantly between animals weaned at two weeks and those weaned at four weeks of age.

For other cuts such as the head, fore limbs and hind limbs the order of weights were four weeks $>$ two weeks $>$ six weeks, whereas for the back and loin cuts, highest values were obtained for animals weaned at six weeks and four weeks respectively. The results of this study negate the reports of Karikari and Nyameasem (2009) who reported significant $(\mathrm{P}<0.05)$ differences for fore limbs, loin and hind limbs. The differences in the results between this study and theirs could be because of weaning age effects.

\subsection{Internal Organ Weights}

The weights of the lung, liver, large intestine, caecum and kidney were not influenced by weaning age of grasscutters (Table 5). In another research on rabbits, Zita et al. (2007) reported significant $(\mathrm{P}<0.05,0.01)$ weaning age effect on proportions of heart and lungs from the carcass. These researchers reported a higher proportion of heart for rabbits weaned at 25 days of age while those weaned at 31 days recorded higher proportion of lungs. The findings of this research showed that grasscutters weaned earlier (two weeks) recorded higher proportions for heart and lungs from carcass and weaning age did not significantly $(\mathrm{P}>0.05)$ affect these organs.

The small intestine was the only organ significantly $(\mathrm{P}<0.05,0.01)$ affected by weaning age of the grasscutters. Statistical analysis revealed that caecum weights across weaning age approached significant level. From the results of this study, weights of the heart and lung followed the order two weeks $>$ four weeks $>$ six weeks. Further observations showed that these organs decreased in weight as weaning age increased. This is an indication that the early weaning of grasscutters ( 2 weeks) in this study could have somehow impacted on the weights of the heart and lung of these animals.

Similarly, caecum weights were also observed to follow the same trend as the heart and lungs. The values were $80.56 \mathrm{~g}, 66.33 \mathrm{~g}$ and $59.88 \mathrm{~g}$, respectively. The large variation within these values could be attributed to the level of development of the digestive system of each group of grasscutters with reference to age.

Xicatto et al. (2003) had reported that caecal fermentation increases as a consequence of increased intake of solid feed. These authors also observed that total volatile fatty acid in the caecal contents of rabbits increased as weaning age decreased. The results obtained in this study could be attributed to this cause since this research was not basically concerned with the contents of the caecum. In addition to this, Piattoni and Maertens (1999) had earlier reported that raising early-weaned kits exclusively on solid feed caused the development of faster fermentation activity thereby increasing the production of volatile fatty acids. As such, changes in caecal fermentation pattern 
seem to depend more on the age of weaning (the beginning of exclusive solid feed intake) than the chronological age of the animal (Xicatto et al., 2003).

\subsection{Relative Organ Weights}

Relative organ weights of grasscutters weaned at different ages are as presented in Table 10. It was observed that the trend in weights varied between organs in carcass weight and organs in relation to live weight. Results of analysis of variance showed that weaning age did not significantly $(\mathrm{P}>0.05)$ affect the parameters measured except for the small intestine. Rao et al. (1978) in earlier study on the effect of weaning age on carcass quality of rabbit meat also reported that weaning age did not have any significant influence on relative organ weights of rabbits. Results of analysis of variance for caecum weights in relation to live weights of the grasscutter presented a definite picture of the extent to which weaning age affected this organ. As observed from the results on the table, grasscutters weaned at two weeks of age recorded the highest significant value of $5.2 \%$ while those weaned at four weeks recorded the least value of $3.55 \%$. The significantly increased proportion of the caecum for grasscutters weaned after two weeks could be explained to be as a result of compensatory growth of this organ to accommodate the change to exclusive intake of solid feed by these animals. The proportions of the liver were similar between grasscutters weaned at two weeks and six weeks, while those weaned at four weeks recorded the highest value although non-significant between the groups. The large intestine weights were seen to follow the order six weeks $>$ four weeks $>$ two weeks. Kidney weights were not also affected by weaning age. Similar results were also reported by Zita et al. (2007) for kidney weights of rabbits weaned at different ages.

\section{Conclusion}

Results of this study revealed that weaning age did not have significant influence on carcass characteristics and internal organ weights of grasscutters. The caecum and small intestine which were significantly affected by weaning age of pups could have been as a result of differences in age and a reflection of each group's ability to utilize solid feed. However, no negative impact was observed in performance across the treatment groups. Therefore, grasscutter pups can be weaned as early as two weeks post parturition without adverse effect on performance.

\section{Reference}

Adu, E. K. (2003). Patterns of parturition and mortality in weaned greater cane rats (Thryonomysswinderianus, Temminck). Tropical Animal Health and Production, 35(5), 425-431. http://dx.doi.org/10.1023/A:1025815528916

Adu, E. K. (2002). Patterns of parturition and mortality in weaned greater cane rats (Thryonomysswinderiarus, Temminck). Tropical Animal Health and Production, 34.

Afifi, E. A., \& Emara, M. E. (1988). Post-weaning viability of pure bred and crossbred rabbits under Egyptian conditions. Journal of Applied Rabbit Research, 1, 38-41.

Ajayi, S. S. (1971). Wildlife as a source of protein n Nigeria: Some priorities for development. The Nigerian Field, 36(3), 115-127.

Ajayi, S. S., \& Tewe, O. O. (1983). A quantitative assessment of wildlife and their nutritive value as a source of food in Nigeria In. Akinyele, I., \& Atome, T. (ed), Nutrition and Food Policy in Nigeria (pp. 138-148). Ibadan, Nigeria: National Institute for Policy and Strategic Studies (NIPSS).

Animal-Care Information Service. (2004). Cane rat (Thryonomis swinderianus). Retrieved from http:llwww.livingfish.co.uk/animal/forum/pop-friendly.asp?Topic-ID=150

Annor, S. Y., Kagya-Agyemang, J. K., Abbam, J. E. Y., Oppeng, S. K., \& Agoe, I. M. (2008). Growth performance of grasscutter (Thryonomis swinderianus) eating leaf and stem fractions of guinea grass (Panicum maximum). Livestock Research for Rural Development, 20, 125.

Attah, S., Omajola, A. B., \& Adesechinwa, A. O. K. (2006). Yield and carcass composition of goats as affected by breed and slaughter weight. World Applied Science Journal, 1(1), 8-11.

Caneque, V. (2001). Effect of weaning and slaughter weight on carcass and meat quality of Talaverana breed lambs raised at pasture. Animal Science, 73(1), 83-95.

Chen, C. P., Rao, D. R., Sunki, G. R., \& Johnson, W. M. (1978). Effect of weaning and slaughter ages upon rabbit meat production: Body weight, feed efficiency and mortality. Journal of Animal Science, 46, 573-577. 
Chineke, C. A., Agaviezor, B., Ikeobi, C. O. N., \& Ologun, A. G. (2002). Some factors affecting body weight and measurements of rabbits at pre and post-weaning ages (pp 1-4). In: Proc. of the 2002 NSAP conference.

Chineke, C. A., Ikeobi, C. O. N., \& Ologun, A. G. (2006). Body measurements of rabbit breeds and crosses at weaning and post-weaning ages. Journal of Biological Sciences, 6(1), 31-37. http://dx.doi.org/10.3923/jbs.2006.31.37

Clottey, S. T., John, A. (1981). Relation of physical body composition to meat yield in the grasscutter (Thryonomysswinderianus -Temminck). Ghana Journal of Science, 21, 1-7.

Duncan, D. B. (1955). Multiple range and multiple F-tests. Biometrics, 11, 1-42. http://dx.doi.org/10.2307/3001478

Fayenuwo, J. O., Akande, M., Taiwo, A. A., Adebayo, A. O., Saka, J. O., Lawal, B., ... Oyekan, P. O. (2003). "Guidelines for Grasscutter Rearing Technical Bulletin-Institute of Agricultural Research and Training. ObafemiAwolowo University, Ibadan, Nigeria.

Fonteh, F. A., Niba, A. T., Kudi, A. C., Tchoumboue, J., \& Awah-Nduku, J. (2005). Influence of weaning age on the growth performance and survival of weaned guinea pigs. Livestock Research for Rural Development, 17(12). Retrieved from www.Irrd.org/Irrd17/12/font17133.htm

Fortun-Lamothe, L., Lamboey-Gaüzere, B., \& Banneliere, C. (2002). Prediction of body composition in rabbit females using electrical conductivity (TOBEC). Liv. Prod. Sci., 78, 133-142. http://dx.doi.org/10.1016/S0301-6226(02)00087-8

Gale, T. (2001). Cane rat. Retrieved from http://www.answers.com/topic/cane-rat

Gallois, M., Gidenne, T., \& Fortun-Lamothe, L. (2003). Digestive development in the young Rabbit: impact of a weaning at 21d. In: Proceeding of $3^{\text {rd }}$ Meeting of Workgroup $3^{\text {rd }}$ and $4^{\text {th }}$ COST Action 848 (pp. 15). Praque, Czech Public.

Gallois, M., Gidenne, T., Fortun-Lamothe, L., Le Huerou-Luron, I., \& Lalles, J. P. (2004). Weaning age and development of the small intestinal mucosa in the young rabbit. In: Proceeding of $8^{\text {th }}$ World Rabbit Congress (pp1079-1085), Pueble, Mexico.

Gillespie, J. R. (1998). Animal Science. Albang: Delmar Publishers.

Henry, A. J., \& Njume, G. N. (2008). Effect of varied energy levels on the carcass characteristics of grasscutters (Thryonomysswinderianus). Proceeding $33^{\text {rd }}$ Annual Conference of Nigerian Society for Animal Production (pp. 168-170), Ogun State.

Idufeko, A. (1984). Self-sufficiency in animal production supply under changing economic fortunes. Nigerian Journal of Animal Production, 11(1), 14-21.

Igben, M. S. (2000). Livestock production in a depressed economy: required adjustment. Proceeding $5^{\text {th }}$ Annual Conference of Animal Science Association of Nigeria (pp. 195-197). Port Harcourt, Nigeria,

Jori, F., Mensah, G. A., \& Adjanohoun, E. (1995). Grasscutter (Thryonomis swinderianus) production: An example of rational exploitation of Wildlife. Biodiversity \& Conservation, 4(2), 257-265.

Karikari, P. K., \& Nyameasem, J. K. (2009). Productive performance and carcass characteristics of captive grasscutters (Thryonomis swinderianus) fed concentrate diets containing varying levels of guinea grass. World Applied Science Journal, 6(4), 557-563.

Kebede, T., Lemma, T., Dinka, H., Guru, M., \& Sisay, A. (2008). Growth performance and carcase characteristics of Arsi-Bale goats castrated at different ages. World Applied Science Journal, 4(4), 545-553.

Lameed, G. A., \& Ogundijo, O. O. (2006). Effect of varied dietary protein levels on the reproductive performance of grasscutter (Thryonomis swinderianus) in captivity. Journal of Animal and Veterinary Advances, 5(5), 361-363.

Madubuike, F. N. (2004). Arresting animal protein insufficiency in Nigeria: A multi-sectional approach. Journal of Agriculture and Food Science, 2(2), 141-149.

Majiyagbe, K. A., \& Lamorde, A. G. (1997). Nationally Coordinated Research Programme on Livestock Diseases: Subsectoral goals, performance and medium-term research plan. Tropical Veterinarian, 15, 75-83.

Martin, G. H. G. (1983). Bushmeat in Nigeria as a natural resource with environmental implications. Environmental Conservation, 10, 125-132. http://dx.doi.org/10.1017/S0376892900012212 
Mbah, L. A. K. (1989). The influence of season and age on the nutritive value of elephant grass (Pennisetumpurpureum) fed to the cane rat (Thryonomis swinderianus). M.Sc. Dissertation, University of Ibadan, Nigeria.

McNitt, J. I., \& Lukefahr, S. D. (1996). Genetic and environmental parameters for post-weaning growth traits of rabbits using an animal model (pp. 325). In: Proc. of the 1996 World Rabbit Science Association, World Rabbit Congress.

Obi, O. O., Omole, A. J., Ajasin, F. O., \& Tewe, O. O. (2008). Nutritive potentials of four conventional forages fed to growing grasscutter (Thryonomis swinderianus). Livestock Research for Rural Development, 20(179).

Ogundola, F. I. (1981). Performance of White Fulani calves weaned at different ages. Tropical Animal Production, 6(4), 336-337.

Ogunjobi, J. A. (2008). Reproductive performances of cane rat (Thryonomis swinderianus Temminck 1827) breeding stocks and litters rate of survival reared using two common housing materials (pp 208-210). Proceeding of $33^{\text {rd }}$ Annual Conference of Nigerian Society for Animal Production, Olabisi Onabanjo University, Ogun State.

Olomu, J. M., Ezieshi, V. E., \& Orheruata, A. M. (2003). Grasscutter Production in Nigeria. Principle and Practice (pp. 61). A Jachem Publication.

Osei, J. A., \& Twumasi, I. K. (1989). Effects of oven-dried cassava peel on the performance and carcass characteristics of broiler chickens. Animal Feed Science Technology, 24, 247-252. http://dx.doi.org/10.1016/0377-8401(89)90146-6

Piattoni, F., \& Maertens, L. (1999). Effect of weaning age and solid feed distribution before weaning on the caecal fermentation pattern of young rabbits. Proceedings of the Arbeitstagunguberkrankheiten der kaninchen, Pelziere and Heimtiere (pp. 97-105). Deutschen Veterinary Medicine. Gesellschaft e. V., Giessen, Germany.

Rao, D. R., Chen, C. P., Sunki, G. R., \& Johnson, W. M. (1978). Effect of weaning slaughter ages on rabbit meat production. II carcass quality and composition. Journal of Animal Science, 46, 578-583.

Schlolaut, W. (1988). Present husbandary and management conditions and development trends in rabbit production. Proceedings of the fourth world rabbit congress (1:13-112), Budapest, Hungary,.

Schrage, R., \& Yewadan, L. T. (1999). In: Raising grasscutters, Deutsche Gesellschaft fur Technische Zusammenarbeit (GTZ) Gmbh (pp 37-47). Eschborn, Germany.

Selaive-Villarroel, A. B., Maciel, M.B., \& de Oliveira, N. M. (2008). Effects of weaning age and weight on lamb growth rate of Morada Nova breed raised in a tropical extensive production system. Ciência Rural, 38(3), 784-788.

Tůmovă, E., Zita, L., Marounek, M., Skřivanova, V., \& Berladyn, A. (2006). The effect of weaning age on performance, nutrient digestibility and lipase activity in broiler rabbits. In: Proceeding $3^{\text {rd }}$ Rabbit Congress of the Americas, Maringa, Brasil CD.

Ugur, F., Savas, T., Dosay, M., Karabayir, A., \& Atasogly, C. (2004). Growth and behavioural traits of Turkish Saanen kids weaned at 45 and 60 days. Small Ruminant Research, 52(1-2), 179-184. http://dx.doi.org/10.1016/S0921-4488(03)00253-0

Van Zyl, A., Meyer, A. J., \& Merwe, V. M. (1999). The influence of fibre in the diet on growth rates and digestibility of nutrients in the greater cane rat (Thryonomis swinderianus). Comparative Biochemistry and Physiology, Part A: Molecular and Integrative Physiology., 123(2), 129-135. http://dx.doi.org/10.1016/S1095-6433(99)00034-3

Wogar, G. S. I., Agwunobi, L. N., \& Anieunam, A. S. (2007). Effect of replacing cassava meal with dried milled elephant grass (Pennisetumpurpureumi) on the performance of growing grasscutters (Thyonomisswinderianusi). In: Proceeding of $32^{\text {nd }}$ Annual Conference of Nigerian Society of Animal Production (pp. 365-368). UNICAL, Calabar,

Xiccato, G., Trocino, A., Sartori, A., \& Queaque, P. I. (2000). Early weaning of rabbits: effect of age and diet on weaning and post-weaning performance. In: proceeding $7^{\text {th }}$ World Rabbit Congress (483-490), Valencia, Spain, $C$. 
Xiccato, G., Trocino, A., Sartori, A., \& Queaque, P. I. (2003). Effect of weaning diet and wearing age on growth, body composition and caecal fermentation of young rabbits. Animal Science, 77, 101-111.

Yakubu, A., Salako, A. E., Ladokun, A. O., Adua, M. M., \& Bature, T. U. K. (2007). Effects of feed restriction on performance, carcass yield, relative organ weights and some linear body measurements of weaner rabbits. Pakistan Journal of Nutrition, 6(4), 391-396. http://dx.doi.org/10.3923/pjn.2007.391.396

Zita, L., Tumova, E., Skrivanova, V., \& Ledvinka, Z. (2007). The effect of weaning age on performance and nutrient digestibility of broiler rabbits. Czech Journal of Animal Science, 52(10), 341-347. 